\title{
Prion infection, transmission and cytopathology modelled in a low-biohazard human cell line
}

Merve Avar $^{1 *}$, Daniel Heinzer ${ }^{1 *}$, Nicolas Steinke ${ }^{1}$, Berre Doğançay ${ }^{1}$, Rita Moos ${ }^{1}$, Severine Lugan $^{2}$,

Claudia Cosenza ${ }^{2}$, Simone Hornemann ${ }^{1}$, Olivier Andréoletti ${ }^{2}$, Adriano Aguzzi $^{1 \S}$

Author affiliations

${ }^{1}$ Institute of Neuropathology, University of Zurich, $\mathrm{CH}-8091$ Zurich, Switzerland

${ }^{2}$ UMR INRA/ENVT 1225 IHAP, École Nationale Vétérinaire de Toulouse (ENVT), 31300, Toulouse, France.

* equal contribution

$\S$ to whom correspondence should be addressed at adriano.aguzzi@usz.ch 


\section{Abstract}

Transmission of prion infectivity to susceptible murine cell lines has simplified prion titration assays and has greatly reduced the need for animal experimentation. However, murine cell models suffer from technical and biological constraints. Human cell lines might be more useful, but they are much more biohazardous and are often poorly infectible. Here we describe the human clonal cell line hovS, which lacks the human $P R N P$ gene and expresses instead the ovine $P R N P V R Q$ allele. HovS cells were highly susceptible to the PG127 strain of sheep-derived murine prions, reaching up to $90 \%$ infected cells in any given culture, and were maintained in a continuous infected state for at least 14 passages. Infected hovS cells produced proteinase K-resistant prion protein $\left(\mathrm{PrP}^{\mathrm{Sc}}\right)$, pelletable PrP aggregates and bona fide infectious prions capable of infecting further generations of naïve hovS cells and mice expressing the VRQ allelic variant of ovine $\operatorname{PrP}^{\mathrm{C}}$. Infection in hovS led to prominent cytopathic vacuolation akin to the spongiform changes observed in individuals suffering from prion diseases. In addition to expanding the toolbox for prion research to human experimental genetics, the hovS cell line provides a humanderived system that does not require human prions. Hence, the manipulation of scrapie-infected hovS cells may present fewer biosafety hazards than that of genuine human prions. 


\section{Introduction}

Prions, the causative agent of transmissible spongiform encephalopathies, are devoid of nucleic acids and consist primarily of a protein termed $\mathrm{PrP}^{\mathrm{Sc}}$. These characteristics differentiate prions from viruses and have profound consequences on the methodologies applicable to their study. Viral replication can be assessed by quantifying the viral nucleic acids, but this is not possible for prions. Moreover, $\mathrm{PrP}^{\mathrm{Sc}}$ cannot be reliably distinguished from its cellular precursor $\operatorname{PrP}^{\mathrm{C}}$ in living cells, making it impossible to assess prion replication in real time. Finally, the study of human prions is fraught with serious biosafety concerns, since prion contaminations of laboratory equipment are difficult to detect, prions are exceedingly sturdy and difficult to inactivate, and there are neither vaccines nor therapies against prion infections (Aguzzi et al., 2018; Leunda et al., 2013; Taylor, 1999; WHO, 2000).

Despite the above obstacles, cellular models of human prion replication and toxicity are crucial to advancing our understanding of human prion diseases. Cell culture models of prion infections have enabled the discovery of certain molecular players responsible for prion infection and propagation. However, most of the in vitro models are based on mouse cell lines such as N2a subclone PK1 (Klöhn et al., 2003), CAD5 and GT-1/7 (Solassol et al., 2003), which may not reproduce all characteristics of human prions. Most importantly, with few exceptions (Schätzl et al., 1997) the infection of these cell lines with prions does not result in a measurable pathological phenotype, a finding that limits their usefulness for disease research.

Currently, there are only three reports of human cellular models for prion infection and propagation (Groveman et al., 2019; Krejciova et al., 2017; Ladogana et al., 1995). However, the culture and maintenance of these models are costly, extremely laborious and have limited scalability. Finally, a major limitation of the above models is that human prions derived from post-mortem brain matter from patients succumbing to Creutzfeldt-Jakob disease (CJD) must be used as inoculum. This raises bioethical issues, requires the availability of a biosafety level-three (BSL3) facility, which restricts the usage to only a few laboratories worldwide, and exposes laboratory workers to potential risks of infection. For all these reasons, the lack of broadly applicable human cell culture models for prion diseases has been a limiting factor in the understanding of the mechanisms behind the formation, propagation, clearance and toxicity of prions.

We reasoned that the problem of biosafety may be attenuated through use of gene replacement. Ovine prions, which cause sheep scrapie, have not been reported to cause prion diseases in humans. Although scrapie is endemic in many sheep flocks (Detwiler and Baylis, 2003; Houston and Andréoletti, 2019), $3 \mid \mathrm{P}$ a g e 
and sheep brain and spinal cord are considered fit for human consumption (EFSA, 2015) in many countries, there is no epidemiological evidence connecting the latter with Creutzfeldt-Jakob disease (CJD) (Brown et al., 1987; Georgsson et al., 2008; van Duijn et al., 1998). Transmission of scrapie to mice expressing human $\operatorname{PrP}^{\mathrm{C}}$ was attempted, but ovine prions arising from VRQ allelic-variant sheep have failed to transmit disease efficiently and mice succumbed to disease only in the second passage (Cassard et al., 2014). While these data do not conclusively prove that sheep prions are innocuous to humans, they suggest that the handling of ovine $\mathrm{PrP}^{\mathrm{Sc}}$ in a laboratory setting may be less dangerous than the manipulation of human prions. Hence the replacement of the human PRNP gene with its ovine counterpart may lead to a cell line that retains all characteristics of human cells while lowering potential biohazards.

Here we used the human neuroblastoma cell line, SH-SY5Y (Pease et al., 2019) with a deletion of the human $P R N P$ gene $\left(\mathrm{SH}-\mathrm{SY} 5 \mathrm{Y}^{\triangle P R N P}\right)$ and inserted instead the Ovis aries PRNP gene (V136-R154-Q171 (VRQ) variant). We report that the resulting clones expressed the ovine $\operatorname{PrP}^{C}$ and were infectible with the ovine prion strain PG127 (Andréoletti et al., 2011). Cells remained permissive for prion propagation through multiple passages and exhibited characteristic prion-induced cytopathic effects. 


\section{Results}

\section{Expression of ovine $\operatorname{PrP}^{C}$ in ovSH-SY5Y cells}

The VRQ allelic variant of sheep $\operatorname{PrP}^{C}$ was reported to convey high susceptibility for ovine prions to xenogenetic cell lines such as the rabbit-kidney RK13 cells (Vilette et al., 2001) and even to invertebrates such as Drosophila melanogaster (Thackray et al., 2018). In order to maximize the likelihood of obtaining a prion-infection permissive cell line, we inserted the ovine $P R N P$ reading frame with the VRQ genotype under the control of the ubiquitous EF1a promoter in SH-SY5Y ${ }^{\triangle P R N P}$. Additionally, the human secretory signal peptide of $\operatorname{PrP}^{\mathrm{C}}$ was added to the ovine PRNP sequence to facilitate proper biogenesis and targeting to the secretory pathway. Stably transfected cells were kept under G418 selection and expanded as a polyclonal bulk (Fig. 1A).

For further experimentation, we isolated a polyclonal cell line, hereafter referred to as "povS" (polyclonal ovine $\mathrm{PrP}^{\mathrm{C}}$ expressing $\mathrm{SH}-\mathrm{SY} 5 \mathrm{Y}^{\triangle P R N P}$ ), as well as a monoclonal cell line obtained through limiting dilution and referred to as "hovS" (monoclonal ovine $\operatorname{PrP}^{\mathrm{C}}$ expressing SH-SY5Y ${ }^{\triangle P R N P}$ ). To characterize the two cell lines, we used western botting and immunocytochemistry. Western blotting showed that the transgenic, ovine $\operatorname{PrP}^{C}$ in both cell lines was expressed at comparable levels as in the two human cell lines, LN229 and U251-MG, and at higher levels as in wildtype (wt) SH-SY5Y cells (Fig. 1B) (Pease et al., 2019). As expected, no expression of $\mathrm{PrP}^{\mathrm{C}}$ was detectable in SH-SY5Y ${ }^{\triangle P R N P}$. Additionally, immunocytochemistry showed an equally distributed staining for ovine $\operatorname{PrP}^{C}$ at the cell surface of the hovS, confirming that $\operatorname{PrP}^{C}$ was localized at the cell membrane, whereas the distribution of $\operatorname{PrP}^{C}$ for the polyclonal povS was more heterogeneous (Fig. 1C). These data indicate that both cell lines express sufficient amounts of cell surface exposed $\mathrm{PrP}^{\mathrm{C}}$ and may thus allow for efficient replication of prions.

\section{Propagation of sheep prions in ovSH-SY5Y cells}

We next investigated the permissiveness of hovS and povS and their capability to replicate sheep prions. We therefore infected the cells $\left(3 \times 10^{5}\right.$ cells $/ 6$ well) with $18.75 \mu$ l/well of a $20 \%$ brain homogenate from PG127 prion-infected tg338 mice expressing the ovine $\operatorname{PrP}^{\mathrm{C}}$ (allelic variant VRQ-VRQ) (Andréoletti et al., 2011). Cells treated with non-infectious brain homogenate (NBH) from C57BL/6J mice were used as control. After three days, the medium was aspirated and cells were passaged numerous times. Several passages were tested for the presence of proteinase $\mathrm{K}(\mathrm{PK})$ resistant $\operatorname{PrP}\left(\operatorname{PrP}^{\mathrm{Sc}}\right)$. At passage8 (used here and henceforth, unless otherwise stated), $\operatorname{PrP}^{\mathrm{Sc}}$ became reliably detectable in the monoclonal hovS as indicated by PK western blotting $(2.5 \mu \mathrm{g} / \mathrm{mL}$ PK for $50 \mu \mathrm{g}$ total protein), but not in 
the polyclonal povS (Fig. 2A, B). Interestingly, the glycosylation pattern and the electrophoretic mobility shifts of $\mathrm{PrP}^{\mathrm{Sc}}$ in hovS differed from those of the original PG127 inoculum and were more reminiscent to those of the previously reported prion-propagating ovinized RK13 cells [0obi:(Vilette et al., 2001) Moreover, the diachronic $\mathrm{PrP}^{\mathrm{C}}$ expression pattern observed on non-PK digested immunoblots showed already increased amounts of PrP post infection, which we hypothesized to be due to the high levels of $\mathrm{PrP}^{\mathrm{Sc}}$ in the ovinized cells.

A hallmark of productive prion infection is the aggregation of misfolded PrP into higher-order structures. We therefore set out to investigate, whether such structures might be present in PG127-infected ovinized SH-SY5Y cells. Cell lysates were separated into supernatant and pelleted fractions and analyzed by immunoblotting with and without PK-digestion using anti-PrP antibody POM1 (Polymenidou et al., 2008) in both fractions, we observed a stronger signal in the concentrated fraction of the PG127-infected hovS and povS cells (Fig. 2C). We conclude that the infected cells indeed formed higher-molecular weight PrP entities upon prion infection. In addition, upon PK digestion, PrP was detected only in the concentrated fraction for both povS and hovS, leading to the conclusion that the detected $\mathrm{PrP}^{\mathrm{Sc}}$ in the infected cells was associated with aggregates. The lack of $\operatorname{PrP}^{\mathrm{Sc}}$ in the knockout cells indicated that it was produced de novo by the ovinized cells and was not due to residual signal arising from the original inoculum. To investigate for the presence of PK-sensitive PrP species and to further examine differences in biochemical properties, a pronase E digestion and western blotting $\left(45 \mathrm{~min}, 37^{\circ} \mathrm{C}, 200 \mu \mathrm{g} / \mathrm{mL}\right.$ for brain homogenate and $20 \mu \mathrm{g} / \mathrm{mL}$ for cell lysate) was performed with lysate of PG127-infected hovS and the original PG127 inoculum. Again, a differential glycosylation pattern and differences in the electrophoretic mobility were detected for PG127-infected hovS and the inoculum (Fig. 2D).

\section{Detection of infected cells at single-cell resolution}

To determine the percentage of infected cells, ELISPOT assays were performed (Arellano-Anaya et al., 2011). Three decadic dilutions of prion-infected hovS and povS (40'000, 4'000 and 400 cells) and NBHtreated and PG127-infected SH-SY5Y ${ }^{\triangle P R N P}$ controls from the same passage were spotted and digested with $\mathrm{PK}$, followed by denaturation with guanidinium thiocyanate and detection with POM1. The percentages of infected cells were found to be $86 \%$ for hovS and $12 \%$ for the povs polyclone ( $n=3$ wells of 400 cells/well) (Fig. 2E). NBH-treated cells and prion-infected SH-SY5Y ${ }^{\triangle P R N P}$ cells remained free of spots at the lowest dilution. We conclude that ovSH-SY5Y cells were permissive for prion infection with 
a high infection rate and that the number of $\operatorname{PrP}^{S c}$ positive cells was dependent on the number of $\operatorname{PrP}^{\mathrm{C}}$ expressing cells.

\section{Cytopathic effects in infected ovSH-SY5Y}

Prion propagation in cell culture has been documented for well over five decades (Clarke and Haig, 1970; Solassol et al., 2003). However, in most instances prion replication does not appear to induce any cytopathic phenotype, except of vacuolation seen in GT-1/7 cells, a mouse GnRH positive cell line of hypothalamic origin infectible with the Rocky Mountain Laboratory (RML) strain of prions (Schätzl et al., 1997). Surprisingly, a vacuolation phenotype (Fig. 2F) in infected hovS cells became evident after three passages post inoculation. Vacuolation increased steadily as cells were kept longer in culture and the phenotype was especially prominent upon splitting. It lessened as the cells grew to confluency and increased in a cyclic manner upon new passaging. This phenomenon was not observed in NBH-treated cells or in SH-SY5Y ${ }^{\triangle P R N P}$ cells inoculated with PG127 prions. In addition, the polyclonal line, povS, did not show an appreciable amount of vacuolation, potentially due to a lower proportion of $\mathrm{PrP}^{\mathrm{C}}$-expressing cells not allowing for large amounts of prion propagation. Infected hovS also displayed impaired cell growth when compared to NBH-treated hovS (Fig. 2G). This further indicates that prion replication led to a dysregulation in cellular metabolic processes.

Investigation of seeding properties of prion-infected ovSH-SY5Y cells

To investigate whether prion-infected ovSH-SY5Y cells exhibited self-propagating activities, lysates of cells from passage 8 were subjected to real-time quaking induced conversion (RT-QuIC) using two different dilutions (1:50 and 1:250) (Atarashi et al., 2011; Frontzek et al., 2016). Both cell lines induced an increase in the Thioflavin T (ThT) signal over 105 hours, whereas the signals for the lysates of NBHtreated cells and of SH-SY5Y ${ }^{\triangle P R N P}$ remained negative (Fig. 3A). This indicates that prions produced by the infected cells are in fact capable to seed $\mathrm{PrP}^{\mathrm{C}}$ into an aggregated form. Intriguingly, povS also showed a delayed ThT signal, in contrast to showing no signal upon PK-western blotting (Fig. 2B).

Lysates from infected cells transmit infectivity to newly inoculated cells and tg338 mice

We then sought out to determine whether the ovinized cells are also able to propagate bona fide prions, herewith defined as microbiologically active infectious agents. To assess whether the newly formed prions could convey infectivity, we inoculated freshly cultured hovS with lysates of PG127-infected hovS cells that had revealed positive seeding activities in the RT-QuIC for three days. Cells were passaged 8 times to dilute out the initial inoculum and to allow for prion propagation. PK-western blotting revealed 7 |P a g e 
that lysates of ovinized cells were capable of conveying infectivity to freshly cultured cells. These results suggest that ovSH-SY5Y produce bona fide prions (Fig. 3B). Moreover, the vacuolation phenotype was also evident in the hovS infected with the lysate of PG127-infected hovS, which is in line with the observation that these cells are permissive for persistent prion infection. To ultimately confirm the bona fide nature of prions produced by the ovinized SH-SY5Y, PG127 infected hovS and SH-SY5Y ${ }^{\triangle P R N P}$ as well as NBH-treated lysates, each harvested in PBS from one well of a 6-well plate were used to inoculate $\operatorname{tg} 338$ mice $(n=6)$. All mice inoculated with lysates of infected hovS succumbed to disease after $72 \pm 2.5$ days, whereas mice inoculated with the control lysates are viable and show no sign of disease 130 days post-inoculation (dpi) (Fig. 3C).

\section{Determining seeding capacities for different substrates}

The strain properties of prions are encoded within the inoculum (Aguzzi and Weissmann, 1997). However, the genetic makeup of the host and environmental factors can shift the properties of prion strains. We therefore examined the seeding properties of prions formed by hovS by measuring their efficiency in seeding substrates from different species. Lysates of PG127-infected hovS, SH-SY5Y ${ }^{\triangle P R N P}$, or NBH-treated cells were applied to the protein misfolding amplification assay (PMCA) (Douet et al., 2017; Lacroux et al., 2014) using brain homogenates from tg338 (ovine VRQ PrP variant), tgARQ (ovine ARQ PrP variant), tgBov (bovine PrP), tg650 (Methionine 129 human PrP variant) and tg361 (Valine 129 human PrP variant) mice as substrates. Lysates of PG127-infected hovS only seeded prion formation with the ovine $\operatorname{PrP}^{C}$ sequence containing substrates, $\operatorname{tg} 338$ and $\operatorname{tg} A R Q$, but not with the bovine $\operatorname{PrP}^{C}$ and human $\operatorname{PrP}^{C}$ sequence containing substrates (Fig. 3C). No seeding activity was detected for the controls, PG127-infected SH-SY5Y ${ }^{\triangle P R N P}$ and NBH-treated cells with any of the substrates. These results imply that the seeding properties of the prions formed by the hovS resemble the original PG127 ovine prions and do not have the propensity to cross the species barrier, despite being produced in a human cell line. 


\section{Discussion}

The VRQ variant of ovine PrP has been reported to convey prion infectibility to a wide range of hosts (Archer et al., 2004; Thackray et al., 2018; Vilette et al., 2001). Here we constructed SH-SY5Y cell lines from which we removed the human $P R N P$ gene, instead expressing the $V R Q$ ovine $\operatorname{PrP}^{C}$ expression under transcriptional control of the housekeeping EF1a promoter. The ovine ER localization signal was swapped with the human sequence, allowing for efficient translocation of the transgenic $\operatorname{PrP}^{\mathrm{C}}$ to the cell surface, where the initial contact between $\operatorname{PrP}^{C}$ and $\operatorname{PrP}^{S c}$ is posited to occur (Goold et al., 2011). Following inoculation with the PG127 prion strain and upon serial passaging, cells accumulated conspicuous PK-resistant aggregates. In addition, $\operatorname{PrP}^{\mathrm{C}}$-expressing hovS cells showed cytosolic vacuolation that continued to steadily increase in subsequent passages. The vacuolation was less conspicuous in persistently infected povS cells, maybe because vacuolation is dependent on the concentration of prions. Collectively, these findings hint at the fact that $\mathrm{PrP}^{\mathrm{Sc}}$-producing cells are not selected against and that mammalian cells possess a machinery to cope with prions to some extent. While protease resistance, aggregation and misfolding are considered proxies of prion generation, the true essence of the prion is its capability to infect organisms and self-propagate therein. The data provided here show that hovS cells produce bona fide prions. These data reinforce the observation that the VRQ-variant of the ovine $\mathrm{PrP}^{\mathrm{C}}$ protein supports prion propagation in disparate genetic backgrounds (Archer et al., 2004; Thackray et al., 2018; Vilette et al., 2001). Additionally, we found that lysates of infected cells functioned as seeds in both the RT-QuIC and the PMCA reactions. Furthermore, such lysates were capable of infecting batches of naive hovS cells, which then accumulated $\operatorname{PrP}^{\mathrm{Sc}}$ and acquired a vacuolation phenotype. Finally and most importantly, lysates of infected hovS cells were found to induce scrapie in tg338 mice with an attack rate of $100 \%$, confirming that these cells were producing bona fide prions.

Cellular models may prove essential to understand the pathways of the rapidly progressing neurodegeneration that follows prion replication in the mammalian brain. However, none of prionpermissive cell lines develop any cytopathological phenotypes in response to prion infection, with the exception of GT-1/7 cells which show mild vacuolation. Additionally, one common limitation of prion infectible cell models is the low percentage of infected cells within each cultured batch (Bosque and Prusiner, 2000; Race et al., 1988). Here we report that the percentage of prion-infected hovS cells was near 90 percent. The high infection rate and the vacuolation phenotype of hovS cells suggest that the rate of prion formation outcompetes the rate of prion clearance in this clone (Krauss and Vorberg, 2013). 
This is also in line with our observation of a slower growth rate of these cells in comparison to NBHtreated cultures. The high infection rate of hovS cells and the conspicuous prion-induced cytopathic effects may be related to the overexpression of $\mathrm{PrP}^{\mathrm{C}}$ which is in contrast to other prion cell models relying on endogenous $\mathrm{PrP}^{\mathrm{C}}$ expression (Vilette, 2008). While overexpression may introduce artifacts in and by itself, it did not appear to cause any cytopathology in the model at hand.

Although SH-SY5Y cells express very low levels of endogenous $\operatorname{PrP}^{\mathrm{C}}$ (Fig. 1B), we elected to inactivate the human PRNP prior to ovinization. Firstly, Host PrP may be a confounding factor for establishment of infectivity in cell models. Attempts in generation of a relevant human model system for prion propagation may have thus far failed due to expression of endogenous $\operatorname{PrP}$ sequestering $\operatorname{PrP}^{\mathrm{Sc}}$ therefore rendering the cell line impermeable for prion replication (Priola et al., 1994). Secondly, we strived to minimize the possibility of the cells replicating human prions in order to protect laboratory workers.

As biosafety is a major concern when working with especially human or bovine prions, we sought to further investigate the possibility of these cells to propagate human prions upon infection with classical scrapie. PK and Pronase E digestion showed that the prions formed by ovinized cells had distinct biochemical properties indicative of a strain shift (Aguzzi et al., 2007). These differences were in line with those seen in other cell lines infected with ovine prions and ectopically expressing ovine $\operatorname{PrP}{ }^{C}$ (Archer et al., 2004; Vilette et al., 2001). It has been suggested that not only the strain, but also the tissue responsible for $\mathrm{PrP}^{\mathrm{Sc}}$ formation can have an influence on the biochemical properties of prions. We utilized RT-QuIC and PMCA as additional approaches to determine seeding properties of the prions, which was reported to faithfully reproduce strain characteristics (Castilla et al., 2008). Indeed, the prions formed by the ovinized cells could only seed ovine $\operatorname{PrP}^{C}$ as a substrate in PMCA, but not human or bovine $\operatorname{PrP}^{C}$. Hence the biochemical identity of the prions the ovSH-SY5Y cells harbor was different from the original PG127 inoculum, yet the seeding properties did not change upon passaging in the human cells. Therefore, we suggest that the cellular machinery of the human cell line SH-SY5Y does not impart an ovine-to-human shift onto prions. The prions produced may have a reduced propensity to infect humans. Moreover, hovS cells do not require human material (such as CJD brain) for infection, in contrast to all previously reported human prion cell models (Groveman et al., 2019; Krejciova et al., 2017; Ladogana et al., 1995). For these combined reasons, we posit that hovS cells may be adopted by many research laboratories worldwide without requiring biosafety level three (BSL3) precautions.

As a caveat, however, the zoonotic potential of ovine prions for humans remains controversial. Although the epidemiological data do not suggest the transmission of prions from sheep to humans (Brown et al., 10| Page 
1987; Georgsson et al., 2008; van Duijn et al., 1998), recent studies using ovine prions to inoculate humanized mice (Cassard et al., 2014) and macaques (Comoy et al., 2015) indicate that ovine prions can cross the species barrier - at least under these specific circumstances. However, the penetrance of prion disease in humanized mice was restricted to the second passage, suggesting that it may require strain adaption. In the macaque study, disease progression was reported only in one individual and only after 110 months with use of a relatively high dose of ovine prions. This is profoundly different from BSE prions which conveyed infectivity to macaques with full penetrance at a much earlier time point and through much lower doses. Considering the WHO recommendation (WHO, 2000) for handling ovine prions in BSL2 facilities the lack of evidence that ovine prions can transmit infectivity to humans, we suggest that scrapie-infected hovS cells should be handled in BSL2 laboratories with utmost caution. The present study demonstrates that the ovinized hovS subclone of engineered SH-SY5Y cells is a robust and flexible model of prion replication and cytopathology. Because hovS cells are wellcharacterized, easy to culture and scalable, they are well-suited for high-throughput applications. This opens hitherto unattainable possibilities to address questions pertinent to prion propagation, infectivity and downstream events in prion pathogenesis in a human cell model which were thus far elusive to the research community. 


\section{Material and Methods}

Generation of a human monoclonal ovinized SH-SY5Y cell line

For ovinization a PRNP knockout ( $P P R N P)$ SH-SY5Y cell line, described earlier (Pease et al., 2019), was used. PRNP coding sequence (CDS, $774 \mathrm{bp}$ ) of Ovis aries harboring the VRQ allele (GeneScript, Piscataway Townsip, NJ, USA), codon optimized for expression in human cell lines and modified to include the human ER localization signal was cloned into the expression vector (Catalog Nr: OGS6065U) under the EF1a promoter (Sigma Aldrich, St. Louis, MO, USA). Positive clones were verified by Sanger sequencing (Microsynth, Balgach, Switzerland). After DNA purification the construct was transfected into cells using Lipofectamine 2000 (Invitrogen, Carlsbad, CA, USA). Following transfection, cells were kept under antibiotic selection and single clones were isolated with limiting dilution. In brief, cells were 12 x serially diluted 1:2 in a 96-well plate (Merck, Darmstadt, Germany) starting with 4000 cells in the first column. Wells with polyclones and single clones were grown to confluency and tested for $\operatorname{PrP}^{C}$ expression. Cells were cultured in OptiMEM (Life Technologies (Gibco), Carlsbad, CA, USA) supplemented with 1\% GlutaMAX (GM), 1\% MEM Non-Essential Amino Acids (MEM-NEAA, Life Technologies), 1\% Penicillin/Streptomycin (PS) (Thermo Fisher Scientific, Waltham, MA, USA) and 10\% FBS (Clontech Laboratories, Mountain View, CA, USA). All cell lines (LN229 (Accession Nr: CRL2611), U251-MG (Accession Nr: CVCL0021), SH-SY5Y wildtype (Accession Nr: CRL2266), and SH-SY5Y ${ }^{\triangle P R N P}$ (Pease et al., 2019') were cultured in $150-\mathrm{cm}^{2}$ Corning cell culture flasks (Merck) and counted using Trypan Blue (Thermo Fisher Scientific) in a TC20 Automated Cell Counter (Bio-Rad Laboratories, Hercules, CA, USA). Ovinized cells were kept under geneticin (G418 sulfate, Life Technologies) selection at a concentration of $400 \mu \mathrm{g} / \mathrm{mL}$ unless stated otherwise. All cells were grown at $37{ }^{\circ} \mathrm{C}$ in a $5 \%$ $\mathrm{CO}_{2}$ atmosphere.

\section{Prion infection of cells}

300 '000 cells were seeded in a 6-well plate (Corning, Corning, NY, USA). The next day, cells were treated with either $0.25 \%(\mathrm{w} / \mathrm{v})$ PG127 produced in tg338 mice or NBH from C57BL/6J mice in a total culture volume of $1.5 \mathrm{~mL}$. After three days, culture medium was replaced with fresh media containing geneticin. Cells were lysed at different passages. Cells at passage 8 were used for assessment of the presence of $\mathrm{PrP}^{\mathrm{Sc}}$, infectivity and seeding properties. For the dissociation of the cells, StemPro Accutase (Thermo Fisher Scientific) was used.

Immunoblot analysis

12 | $\mathrm{P}$ a g e 
For lysis, cells were washed once with PBS and scraped with lysis buffer $(50 \mathrm{mM}$ Tris- $\mathrm{HCl} \mathrm{pH} 8,150$ $\mathrm{mM} \mathrm{NaCl}, \quad 0.5 \%$ sodium deoxycholate, $0.5 \%$ Triton-X 100). Total protein concentrations were determined with a bicinchoninic acid assay according to the manufacturer's instructions (Pierce, Waltham, MA, USA). Proteinase K (PK, Roche AG, Basel, Switzerland) digestion was performed at a final concentration of $2.5 \mu \mathrm{g} / \mathrm{mL}$ for cell lysates and $25 \mu \mathrm{g} / \mathrm{mL}$ for brain homogenates for 30 minutes at $37^{\circ} \mathrm{C}$. Pronase E (Protease from Streptomyces griseus Type XIV, Sigma Aldrich) was diluted in water to a concentration of $2 \mathrm{mg} / \mathrm{mL}$. Final concentration of Pronase $\mathrm{E}$ used was $200 \mu \mathrm{g} / \mathrm{mL}$ for brain homogenates and $20 \mu \mathrm{g} / \mathrm{mL}$ for cell lysates. Digestion was performed for 45 minutes at $37^{\circ} \mathrm{C}$ and terminated by boiling the samples in LDS (Invitrogen, Carlsbad, CA, USA) containing 1 mM DTT (Sigma Aldrich). Samples were loaded onto a $4-12 \%$ gradient gel (Invitrogen) and blotted onto a PVDF or nitrocellulose membrane (Invitrogen). Monoclonal anti-PrP POM1 or POM2 antibody (Polymenidou et al., 2008) was diluted to $300 \mathrm{ng} / \mathrm{mL}$ in $1 \%$ SureBlock (LuBio Sciences, Zurich, Switzerland) containing PBS-Tween20 (PBST, Sigma Aldrich) and incubated overnight at $4^{\circ} \mathrm{C}$. Anti-Mouse HRP (BioRad) was used as a secondary detection antibody and immunoblots were developed with Forte HRP substrate (Millipore, Dachstein, France). Anti-Actin antibody m25 (Merck) was used at a dilution of 1:10000 in 1\%Sureblock containing PBST as a loading control. Imaging was performed on either FUJI-FILM LAS3000 (Fujifilm, Tokyo, Japan) or Vilber (Eberhardzell, Germany) systems.

Aggregate enrichment was performed by centrifugation of a total of $150 \mu \mathrm{g}$ protein at 20 ' $800 \mathrm{~g}$ in a tabletop centrifuge (Eppendorf $5417 \mathrm{r}$, Hamburg, Germany) for 1 hour at $4^{\circ} \mathrm{C}$. For the analysis of the supernatant, $20 \mu \mathrm{L}$ of the sample was isolated and further processed as described above. For the aggregate-enriched fraction, the remaining $20 \mu \mathrm{L}$ of the total volume were either protease digested or analyzed directly by SDS-PAGE and western blotting as described above.

\section{Immunocytochemistry and live imaging}

Immunocytochemistry was performed by seeding 20 '000 cells on coverslips (Thermo Fisher Scientific) coated with a poly-L-lysine solution (Sigma Aldrich). Fixation was done 24 hours after seeding with $4 \%$ paraformaldehyde (PFA, Roth, Karlsruhe, Germany). Anti-PrP staining was performed with POM1 $(3.8 \mu \mathrm{g} / \mathrm{mL})$ in PBS supplemented with $0.5 \%$ BSA for 1 hour. As a secondary antibody, goat anti-mouse coupled to AlexaFluor 488 (Invitrogen) was used at a final dilution of $1: 400$ in $0.5 \%$ BSA in PBS. Additionally, DAPI (Sigma Aldrich) was used at $1 \mu \mathrm{g} / \mathrm{mL}$ during the incubation with the secondary antibody. Cells were washed with $0.5 \%$ BSA in PBS between each incubation step for four times. 
Coverslips were mounted on slides using a mounting solution overnight (Agilent Technologies, Santa Clara, CA, USA). Imaging was performed on Leica TCS SP5 (Leica Microsystems, Heerbrugg, Switzerland). For the comparison of the cell growth of PG127-infected and NBH-treated hovS, 20`000 cells/well were seeded in culture medium in 24-well plates ( $n=6$ for each condition), imaged and analyzed with a confluency mask using the Incucyte ZOOM system (Essen Biosciences, Ann Arbor, MI, USA). A student's t-test was performed for the final timepoint (180 hours in culture). Vacuolation was imaged with the Incucyte ZOOM system. Data were depicted with GraphPad Prism 8 (GraphPad Inc., La Jolla, CA, USA).

\section{ELISPOT for the detection of infected single cells}

ELISPOT membranes (Millipore) were activated by adding $50 \mu \mathrm{L}$ filtered ethanol/well and washed twice with $160 \mu \mathrm{L}$ PBS. Three different dilutions of cells per well (40'000, 4'000 and 400) were spotted onto the membrane and dried with a plate thermomixer (Eppendorf) at $50^{\circ} \mathrm{C}$. For the control wells, $40^{\circ} 000$ cells were used. After drying, plates were stored at $4{ }^{\circ} \mathrm{C}$ until further processing. $50 \mu \mathrm{L}$ of $0.5 \mu \mathrm{g} / \mathrm{mL} \mathrm{PK}$ in lysis buffer was added to each well and incubated for 90 minutes at $37^{\circ} \mathrm{C}$. Following incubation, vacuum was applied to discard the contents and wells were washed twice with $160 \mu \mathrm{L}$ PBS. To stop digestion, $160 \mu \mathrm{L}$ of $2 \mathrm{mM}$ PMSF (Sigma Aldrich) diluted in PBS was added to the membrane and incubated at room temperature for 10 minutes. Tris guanidinium thiocyanate was prepared by diluting $3 \mathrm{M}$ guanidinium thiocyanate (Sigma Aldrich) in $10 \mathrm{mM}$ Tris $\mathrm{HCl}, \mathrm{pH} 8$, and $160 \mu \mathrm{L} /$ well was added to each membrane. After incubation for 10 minutes, the supernatant was discarded into $2 \mathrm{M} \mathrm{NaOH}$ and each membrane was washed seven times with $160 \mu \mathrm{L}$ PBS and blocked for 1 hour with $160 \mu \mathrm{L}$ SuperBlock (Thermo Fisher Scientific) prepared in MilliQ. Remaining blocking solution was removed under vacuum and $50 \mu \mathrm{L}$ POM1 was added at a dilution of 1:5000 in TBST (10 mM Tris HCl, pH 8, $150 \mathrm{mM} \mathrm{NaCl}, 0.1 \%(\mathrm{v} / \mathrm{v})$ Tween 20$)$ containing $1 \%(\mathrm{w} / \mathrm{v})$ non-fat dry milk for 1 hour. The supernatant was discarded into $2 \mathrm{M} \mathrm{NaOH}$ and wells were subsequently washed seven times with TBST under vacuum. $50 \mu \mathrm{L}$ of anti-lgG1-AP (Southern Biotechnology Associates, Birmingham, AL, USA) was used at a 1:4500 dilution in TBST-1\% (w/v) non-fat dry milk and incubated for 1 hour. Discarding of the supernatant and washing was performed in the same way as the POM1 antibody. $50 \mu \mathrm{L}$ of colorimetric AP dye (BioRad) was applied and incubated for 16 minutes. Membranes were washed twice with water, dried and stored at $-20^{\circ} \mathrm{C}$ in the dark. Quantification was performed by counting PK-resistant spots. Data were visualized using GraphPad Prism 8 (GraphPad Software, Inc.). 


\section{RT-QulC assay}

The reaction buffer of the RT-QulC consisted of HaPrP23-231 filtered using $100 \mathrm{kDa}$ centrifugal filters (Pall Nanosep OD100C34) at a concentration of $0.1 \mathrm{mg} / \mathrm{mL}, 1 \mathrm{mM}$ EDTA (Life Technologies), $10 \mu \mathrm{M}$ Thioflavin T, $170 \mathrm{mM} \mathrm{NaCl}$ and 1x PBS (incl. $130 \mathrm{mM} \mathrm{NaCl}$ ). Cell lysis was performed in PBS with three freeze-thaw cycles. $2 \mu \mathrm{L}$ of the lysates were used at two different dilutions (1:50 and 1:250) to assess seeding activity. The RT-QuIC assay was performed in accordance with the previously established protocols (Atarashi et al., 2011; Frontzek et al., 2016). The plate was loaded into a FLUOstar Omega plate reader (BMG Labtech, Ortenberg, Germany) and the shaking cycles were set to: (7x (90 sec shaking (900 rpm (double orbital), $30 \mathrm{sec}$ rest)), $60 \mathrm{sec}$ reading. Reading was carried out with excitation at $450 \mathrm{~nm}$ and emission at $480 \mathrm{~nm}$ every $15 \mathrm{~min}$. The amplification was performed at $42{ }^{\circ} \mathrm{C}$ for $105 \mathrm{~h}$. Four replicates per sample were measured.

\section{$P M C A$}

Cell lysates were prepared in PBS with repeated freeze thaw cycles as described for the RT-QuIC. Brains from tg110 (bovine PrP expressing mice), tgShpXI (Ovine ARQ variant expressing mice), tg338 (Ovine VRQ variant expressing mice) and tg650 (Methionine 129 human PrP expressing mice) were used to prepare the PMCA substrates (Lacroux et al., 2014). PMCA was performed as previously described (Douet et al., 2017). Briefly, PMCA reactions (50 $\mu \mathrm{L}$ final volume) were seeded with $5 \mu \mathrm{L}$ of sample to be tested. PMCA reactions were then subjected to 3 amplification rounds each comprising 96 cycles (10s sonication-14 minutes and 50 seconds incubation at $39.5^{\circ} \mathrm{C}$ ) in a Qsonica700. After each round reaction products ( 1 volume) were mixed with fresh substrate (9 volumes) to seed the following round. The PMCA reaction products were analysed by western blot for the presence of $\operatorname{PrP}^{\mathrm{Sc}}$ (material equivalent to $20 \mu \mathrm{L}$ of PMCA product per lane). Each PMCA run included a reference ovine scrapie (PG127) and ovine BSE sample (10\% brain homogenate dilution series) as a control for the amplification efficiency. Unseeded controls ( 2 unseeded controls for 8 seeded reactions) were also included in each run. $\operatorname{PrP}^{\mathrm{Sc}}$ extraction and western blotting was performed as previously described (Huor et al., 2017). Immunodetection was performed using an anti-PrP antibody, Sha31 (1 $\mu \mathrm{g} / \mathrm{mL})$ (Féraudet et al., 2005), which recognizes the amino acid sequences YEDRYYRE (145-152).

\section{Mouse Bioassay}

All animal experiments were performed in compliance with institutional and French national guidelines in accordance with the European Union Directives 86/609/EEC and 2010/63/EU. Experiments were 
approved by the Committee on the Ethics of Animal Experiments of the author's institutions: INRA Toulouse/ENVT (Permit Number: 01734.01)

Mouse bioassays were carried out in ovine VRQ PrP transgenic mice (tg338), which are considered to be highly efficient for the detection of sheep scrapie infectivity (Le Dur et al., 2005). High sensitivity of $\operatorname{tg} 338$ mice for detection of PG127 scrapie isolate was previously reported (Andréoletti et al., 2011). At least six mice were intracerebrally inoculated with each sample $(20 \mu \mathrm{L})$. Mice were clinically monitored until the occurrence of TSE clinical signs, upon which time they were sacrificed.

\section{Acknowledgements}

AA is the recipient of an Advanced Grant of the European Research Council and grants from the Swiss National Research Foundation, the Nomis Foundation, the Swiss Personalized Health Network (SPHN, 2017DRI17), and a donation from the estate of Dr. Hans Salvisberg.

\section{Author Contributions:}

Conceived and designed the experiments: MA, DH, SH, AA. Supervised the study: SH, OA, AA. Performed the experiments and analyzed the data: MA, DH, NS, BD, RM, SL, CC. Wrote the paper: MA, DH, SH, AA. 


\section{References:}

Aguzzi, A., Heikenwalder, M., and Polymenidou, M. (2007). Insights into prion strains and neurotoxicity. Nat Rev Mol Cell Biol 8, 552-561.

Aguzzi, A., Lakkaraju, A.K.K., and Frontzek, K. (2018). Toward Therapy of Human Prion Diseases. Annu Rev Pharmacol Toxicol 58, 331-351.

Aguzzi, A., and Weissmann, C. (1997). Prion research: the next frontiers. Nature 389, 795-798.

Andréoletti, O., Orge, L., Benestad, S.L., Beringue, V., Litaise, C., Simon, S., Le Dur, A., Laude, H., Simmons, H., Lugan, S., et al. (2011). Atypical/Nor98 scrapie infectivity in sheep peripheral tissues. PLoS Pathog 7, e1001285.

Archer, F., Bachelin, C., Andreoletti, O., Besnard, N., Perrot, G., Langevin, C., Le Dur, A., Vilette, D., Baron-Van Evercooren, A., Vilotte, J.L., et al. (2004). Cultured peripheral neuroglial cells are highly permissive to sheep prion infection. J Virol 78, 482-490.

Arellano-Anaya, Z.E., Savistchenko, J., Mathey, J., Huor, A., Lacroux, C., Andréoletti, O., and Vilette, D. (2011). A simple, versatile and sensitive cell-based assay for prions from various species. PLoS One 6, e20563.

Atarashi, R., Satoh, K., Sano, K., Fuse, T., Yamaguchi, N., Ishibashi, D., Matsubara, T., Nakagaki, T., Yamanaka, H., Shirabe, S., et al. (2011). Ultrasensitive human prion detection in cerebrospinal fluid by real-time quaking-induced conversion. Nat Med 17, 175-178.

Bosque, P.J., and Prusiner, S.B. (2000). Cultured cell sublines highly susceptible to prion infection. J Virol 74, 4377-4386.

Brown, P., Cathala, F., Raubertas, R.F., Gajdusek, D.C., and Castaigne, P. (1987). The epidemiology of Creutzfeldt-Jakob disease: conclusion of a 15-year investigation in France and review of the world literature. Neurology 37, 895-904.

Cassard, H., Torres, J.M., Lacroux, C., Douet, J.Y., Benestad, S.L., Lantier, F., Lugan, S., Lantier, I., Costes, P., Aron, N., et al. (2014). Evidence for zoonotic potential of ovine scrapie prions. Nat Commun $5,5821$.

Castilla, J., Morales, R., Saá, P., Barria, M., Gambetti, P., and Soto, C. (2008). Cell-free propagation of prion strains. EMBO J 27, 2557-2566.

Clarke, M.C., and Haig, D.A. (1970). Evidence for the multiplication of scrapie agent in cell culture. Nature 225, 100-101.

Comoy, E.E., Mikol, J., Luccantoni-Freire, S., Correia, E., Lescoutra-Etchegaray, N., Durand, V., Dehen, C., Andreoletti, O., Casalone, C., Richt, J.A., et al. (2015). Transmission of scrapie prions to primate after an extended silent incubation period. Sci Rep 5, 11573.

Detwiler, L.A., and Baylis, M. (2003). The epidemiology of scrapie. Rev Sci Tech 22, 121-143.

Douet, J.Y., Lacroux, C., Aron, N., Head, M.W., Lugan, S., Tillier, C., Huor, A., Cassard, H., Arnold, M., Beringue, V., et al. (2017). Distribution and Quantitative Estimates of Variant Creutzfeldt-Jakob Disease Prions in Tissues of Clinical and Asymptomatic Patients. Emerg Infect Dis 23, 946-956.

EFSA, P.o.B.H. (2015). Scientific Opinion on a request for a review of a scientific publication concerning the zoonotic potential of ovine scrapie prions, E.F.S. Authority, ed. (EFSA Journal: Wiley).

Féraudet, C., Morel, N., Simon, S., Volland, H., Frobert, Y., Créminon, C., Vilette, D., Lehmann, S., and Grassi, J. (2005). Screening of 145 anti-PrP monoclonal antibodies for their capacity to inhibit PrPSc replication in infected cells. J Biol Chem 280, 11247-11258.

Frontzek, K., Pfammatter, M., Sorce, S., Senatore, A., Schwarz, P., Moos, R., Frauenknecht, K., Hornemann, S., and Aguzzi, A. (2016). Neurotoxic Antibodies against the Prion Protein Do Not Trigger Prion Replication. PLoS One 11, e0163601.

Georgsson, G., Olafsson, E., and Gudmundsson, G. (2008). [Scrapie of sheep and Creutzfeldt-Jakob disease in Iceland]. Laeknabladid 94, 541-548.

Goold, R., Rabbanian, S., Sutton, L., Andre, R., Arora, P., Moonga, J., Clarke, A.R., Schiavo, G., Jat, P., Collinge, J., et al. (2011). Rapid cell-surface prion protein conversion revealed using a novel cell system. Nat Commun 2, 281.

Groveman, B.R., Foliaki, S.T., Orru, C.D., Zanusso, G., Carroll, J.A., Race, B., and Haigh, C.L. (2019). Sporadic Creutzfeldt-Jakob disease prion infection of human cerebral organoids. Acta Neuropathol Commun 7, 90.

Houston, F., and Andréoletti, O. (2019). Animal prion diseases: the risks to human health. Brain Pathol $29,248-262$.

Huor, A., Douet, J.Y., Lacroux, C., Lugan, S., Tillier, C., Aron, N., Cassard, H., Arnold, M., Torres, J.M., Ironside, J.W., et al. (2017). Infectivity in bone marrow from sporadic CJD patients. J Pathol 243, 273278. 
Klöhn, P.C., Stoltze, L., Flechsig, E., Enari, M., and Weissmann, C. (2003). A quantitative, highly sensitive cell-based infectivity assay for mouse scrapie prions. Proc Natl Acad Sci U S A 100, 1166611671.

Krauss, S., and Vorberg, I. (2013). Prions Ex Vivo: What Cell Culture Models Tell Us about Infectious Proteins. Int J Cell Biol 2013, 704546.

Krejciova, Z., Alibhai, J., Zhao, C., Krencik, R., Rzechorzek, N.M., Ullian, E.M., Manson, J., Ironside, J.W., Head, M.W., and Chandran, S. (2017). Human stem cell-derived astrocytes replicate human prions in a. J Exp Med 214, 3481-3495.

Lacroux, C., Comoy, E., Moudjou, M., Perret-Liaudet, A., Lugan, S., Litaise, C., Simmons, H., Jas-Duval, C., Lantier, I., Béringue, V., et al. (2014). Preclinical detection of variant CJD and BSE prions in blood. PLoS Pathog 10, e1004202.

Ladogana, A., Liu, Q., Xi, Y.G., and Pocchiari, M. (1995). Proteinase-resistant protein in human neuroblastoma cells infected with brain material from Creutzfeldt-Jakob patient. Lancet 345, 594-595.

Le Dur, A., Béringue, V., Andréoletti, O., Reine, F., Laï, T.L., Baron, T., Bratberg, B., Vilotte, J.L., Sarradin, P., Benestad, S.L., et al. (2005). A newly identified type of scrapie agent can naturally infect sheep with resistant PrP genotypes. Proc Natl Acad Sci U S A 102, 16031-16036.

Leunda, A., Van Vaerenbergh, B., Baldo, A., Roels, S., and Herman, P. (2013). Laboratory activities involving transmissible spongiform encephalopathy causing agents: risk assessment and biosafety recommendations in Belgium. Prion 7, 420-433.

Pease, D., Scheckel, C., Schaper, E., Eckhardt, V., Emmenegger, M., Xenarios, I., and Aguzzi, A. (2019). Genome-wide identification of microRNAs regulating the human prion protein. Brain Pathol 29, 232-244.

Polymenidou, M., Moos, R., Scott, M., Sigurdson, C., Shi, Y.Z., Yajima, B., Hafner-Bratkovic, I., Jerala, R., Hornemann, S., Wuthrich, K., et al. (2008). The POM monoclonals: a comprehensive set of antibodies to non-overlapping prion protein epitopes. PLoS One 3, e3872.

Priola, S.A., Caughey, B., Race, R.E., and Chesebro, B. (1994). Heterologous PrP molecules interfere with accumulation of protease-resistant PrP in scrapie-infected murine neuroblastoma cells. J Virol 68, 4873-4878.

Race, R.E., Caughey, B., Graham, K., Ernst, D., and Chesebro, B. (1988). Analyses of frequency of infection, specific infectivity, and prion protein biosynthesis in scrapie-infected neuroblastoma cell clones. J Virol 62, 2845-2849.

Schätzl, H.M., Laszlo, L., Holtzman, D.M., Tatzelt, J., DeArmond, S.J., Weiner, R.I., Mobley, W.C., and Prusiner, S.B. (1997). A hypothalamic neuronal cell line persistently infected with scrapie prions exhibits apoptosis. J Virol 71, 8821-8831.

Solassol, J., Crozet, C., and Lehmann, S. (2003). Prion propagation in cultured cells. Br Med Bull 66, 87-97.

Taylor, D.M. (1999). Inactivation of prions by physical and chemical means. J Hosp Infect 43 Suppl, S69-76.

Thackray, A.M., Andréoletti, O., and Bujdoso, R. (2018). Mammalian prion propagation in PrP transgenic Drosophila. Brain 141, 2700-2710.

van Duijn, C.M., Delasnerie-Lauprêtre, N., Masullo, C., Zerr, I., de Silva, R., Wientjens, D.P., Brandel, J.P., Weber, T., Bonavita, V., Zeidler, M., et al. (1998). Case-control study of risk factors of CreutzfeldtJakob disease in Europe during 1993-95. European Union (EU) Collaborative Study Group of Creutzfeldt-Jakob disease (CJD). Lancet 351, 1081-1085.

Vilette, D. (2008). Cell models of prion infection. Vet Res 39, 10.

Vilette, D., Andreoletti, O., Archer, F., Madelaine, M.F., Vilotte, J.L., Lehmann, S., and Laude, H. (2001). Ex vivo propagation of infectious sheep scrapie agent in heterologous epithelial cells expressing ovine prion protein. Proc Natl Acad Sci U S A 98, 4055-4059.

WHO (2000). WHO Infection Control Guidelines for Transmissible Spongiform Encephalopathies, WHO, ed. 


\section{Figure legends}

Figure 1. Generation and characterization of the ovinized SH-SY5Y cell lines. (A) Generation of SH-SY5Y $Y^{\triangle P R N P}$ cell lines expressing the ovine $V R Q \operatorname{PrP}^{C}$ variant and its subsequent infection with the PG127 strain of sheep-derived prions passaged in tg338 mice. HindIII and EcoRI restriction sites were used to clone the ovine PRNP construct. Ticks in the plasmid map correspond to increments of 1000 base pairs. hSP = human signal peptide (purple), oSP = ovine signal peptide (blue), hovS = monoclonal ovSH-SY5Y, povS = polyclonal ovSH-SY5Y, ovSH-SY5Y $=$ SH-SY5Y ${ }^{\triangle P R N P}$ transfected with a plasmid harboring the sequence for ovine PRNP (ovPRNP). (B) Western blot analysis comparing the expression levels of $\operatorname{PrP}^{\mathrm{C}}$ in hovS and povS with those in wt SH-SY5Y and in the human cell lines U251-MG and LN229. HovS and povS showed similar $\operatorname{PrP}^{\mathrm{C}}$ expression levels as U251-MG and LN229, whereas the levels in wt SH-SY5Y were slightly lower. SH-SY5Y ${ }^{\triangle P R N P}$ cells were used as negative control and actin as loading control. The anti-PrP antibody POM2 was used for detection. (C) Confocal imaging to detect cell surface exposed $\mathrm{PrP}^{\mathrm{C}}$ on hovS and povS. hovS and a subpopulation of povS showed a strong signal for cell surface exposed $\mathrm{PrP}^{\mathrm{C}}$, whereas no detectable signal was visible for SH-SY5Y ${ }^{\triangle P R N P}$. LN229 cells were used as positive control. The anti-PrP antibody POM1 (here and henceforth) was used for detection of PrP.

Figure 2. PG127-infected povS and hovS show altered electrophoretic profiles, formation of protease resistant $\mathrm{PrP}^{\mathrm{Sc}}$, and enhanced cytopathic effects. (A) Western blot analysis of PG127infected povS and hovS cells indicated a different glycosylation pattern, a shift in the electrophoretic mobility, and partially protease-resistant $\operatorname{PrP}^{\mathrm{Sc}}$, when compared to $\mathrm{NBH}$ exposed-hovS. Rightmost lanes: NBH and PG127-infected brain homogenate. PG127-infected SH-SY5Y ${ }^{\triangle P R N P}$ lysate was used as negative control. $-\mathrm{PK}=$ non-PK digested. $(\mathrm{B})$ Same samples as in $(\mathrm{A})$, but digested with $\mathrm{PK}$. $\mathrm{PrP}^{\mathrm{Sc}}$ is visible in PG127-infected hovS and the PG127 inoculum. No detectable bands are visible for PG127infected povS, possibly because of the lower expression of $\operatorname{PrP}^{C}$ in these cells. (C) Western blot analysis of pellets and supernatants of cell lysates. The aggregate-enriched pellets of PG127-infected povS and hovS displayed a stronger signal for both total PrP and PrP ${ }^{\mathrm{Sc}}$. PG127-infected SH-SY5Y ${ }^{\triangle P R N P}, \mathrm{NBH}$ and the original PG127 inoculate were used as controls. (D) Western blot analysis of pronase E-digested PG127-infected hovS, to investigate the presence of PK-sensitive PrP ${ }^{\mathrm{Sc}}$. PG127-infected hovS differed again in their protease resistance pattern from those of the original PG127 inoculum. NBH, non-digested PG127 inoculum and lysate of non-digested PG127-infected hovS were used as controls. (E) ELISpot 19|P a g e 
assay of PG127-infected hovS and povS, visualizing cells harboring $\mathrm{PrP}^{\mathrm{Sc}}$. Membranes were exposed to decadic dilutions of PG127-infected hovS and povS cell suspensions, PK-digested, and stained with POM1. Positive cells were counted on membranes with 400 cells, as a higher cell numbers led to signal saturation in hovS cells. Quantification of positive spots (three replicates) revealed $86 \pm 12.5 \%$ of infected cells for hovS, and $12 \pm 2.7 \%$ for povS. No positive spots were detected for NBH-treated hovS and povS and PG127-infected SH-SY5Y ${ }^{\triangle P R N P}$ at $40^{\prime} 000$ cells. Data in the graph represent the mean \pm standard deviation (SD). (F) Phase contrast image of PG127-infected hovS showing intracellular accumulation of vacuoles (arrows). Scale bar $=50 \mu \mathrm{m}$. (G) PG127-infected hovS showed a slower growth rate than $\mathrm{NBH}$-treated hovS over 180 hours in culture. Live images were recorded from $n=6$ wells for each condition. ${ }^{* * *} p=0.0004$ (Student's t-test at final time point).

Figure 3. Self-propagating activity and transmissibility of PG127-infected hovS and povS. (A) The seeding activity of PG127-infected or NBH-treated hovS, povS and SH-SY5Y ${ }^{\triangle P R N P}$ lysates was assessed by RT-QuIC (diluted 1:50 and 1:250). PG127-infected hovS, and to a lesser extent povS cells, induced de novo PrPaggregate formation at both dilutions, whereas cell lysates of either NBH-treated or PG127infected SH-SY5Y ${ }^{\triangle P R N P}$ used as negative controls did not yield a positive signal. CJD and non-CJD brain homogenates were used as positive and negative controls for the amplification reaction. Samples were analyzed in quadruplicates. (B) Western blot analysis of serial transmissibility. PG127-infected hovS cell lysates (PG hovS) were used to transmit prion infectivity to fresh hovS cultures. Lysates of undigested and PK-digested hovS exposed to PG127-infected hovS lysates displayed the same electrophoretic profiles as the original lysates. Lysates of hovS exposed to NBH-treated hovS and PG127-infected SHSY $5 \mathrm{Y}^{\triangle P R N P}$ cells were used as negative controls. NBH and PG127 inoculum were loaded as additional controls (rightmost lanes). (C) Lysates $(20 \mu \mathrm{l})$ of PG127-infected hovS and SH-SY5Y $\mathrm{Y}^{\triangle P R N P}$ or NBHtreated hovS were intracerebrally inoculated into tg338 mice. All mice succumbed to disease upon inoculation with PG127-infected hovS lysates with an incubation time of $72 \pm 2.5$ days. Mice inoculated with control lysates do not show any clinical sign of disease $>130$ (dpi). $n=6$ for each condition. (D) Lysates of PG127-infected hovS (diluted 1:50) were analyzed for propagation efficiency and substrate specificity by PMCA using substrates from various species and of different genotypes (sheep VRQ/VRQ (tg338), sheep ARQ/ARQ (tgARQ), bovine (tgbov), human 129Met ( $\operatorname{tg} 650)$, human 129V $(\operatorname{tg} 361))$. PMCA reactions of the third round were analyzed for $\mathrm{PrP}^{\mathrm{Sc}}$ by Western blotting. Lysates of PG127infected hovS cells showed positive seeding reactions only with the ovine substrates. NBH-treated hovS 
and PG127-infected SH-SY5Y ${ }^{\triangle P R N P}$ were used as negative controls and PG127, BSE and SCJD prions amplified with the respective substrates as positive controls. Reference: PG127 inoculum used to control for signal intensity and band shifts. One representative data set from three experiments is shown.

Supplementary Figure 1. Uncropped and unmodified western blot images of Main Figure 1. (A) Uncropped western blot image of Main Figure 1B probed with anti-PrP antibody POM2. (B) Same image as in (A) showing the size marker. (C) Same western blot as in (A) probed with the anti-actin antibody m25. (D) Same western blot image as in (C) showing the size marker for anti-actin antibody.

\section{Supplementary Figure 2. Uncropped and unmodified western blot images of Main Figure 2. (A)} Uncropped western blot image of Main Figure 2A probed with anti-PrP antibody POM1. (B) Same image as in (A) showing the size marker. (C) Same western blot as in (A) probed with the anti-actin antibody m25. (D) Same western blot image as in (C) showing the size marker for anti-actin antibody. (E) Uncropped western blot image of Main Figure 2B probed with anti-PrP antibody POM1. (F) Same image as in (E) showing the size marker. (G) Uncropped western blot image of Main Figure 2C -PK probed with anti-PrP antibody POM1. (H) Same image as in (G) showing the size marker. (I) Uncropped western blot image of Main Figure 2C +PK probed with anti-PrP antibody POM1. (J) Same image as in (I) showing the size marker. (K) Uncropped western blot image of Main Figure 2D probed with anti-PrP antibody POM1. (L) Same image as in (K) showing the size marker.

\section{Supplementary Figure 3. Uncropped and unmodified western blot images of Main Figure 3. (A)} Uncropped western blot image of Main Figure 3 with PMCA products on tg338 substrate probed with anti-PrP antibody Sha31. (B) Uncropped western blot image of Main Figure 3 with PMCA products on $\operatorname{tg} A R Q$ substrate probed with anti-PrP antibody Sha31. (C) Uncropped western blot image of Main Figure 3 with PMCA products on tg650 substrate probed with anti-PrP antibody Sha31. (D) Uncropped western blot image of Main Figure 3 with PMCA products on tg361 substrate probed with anti-PrP antibody Sha31. (E) Uncropped western blot image of Main Figure 3 with PMCA products on tgBov substrate probed with anti-PrP antibody Sha31. 

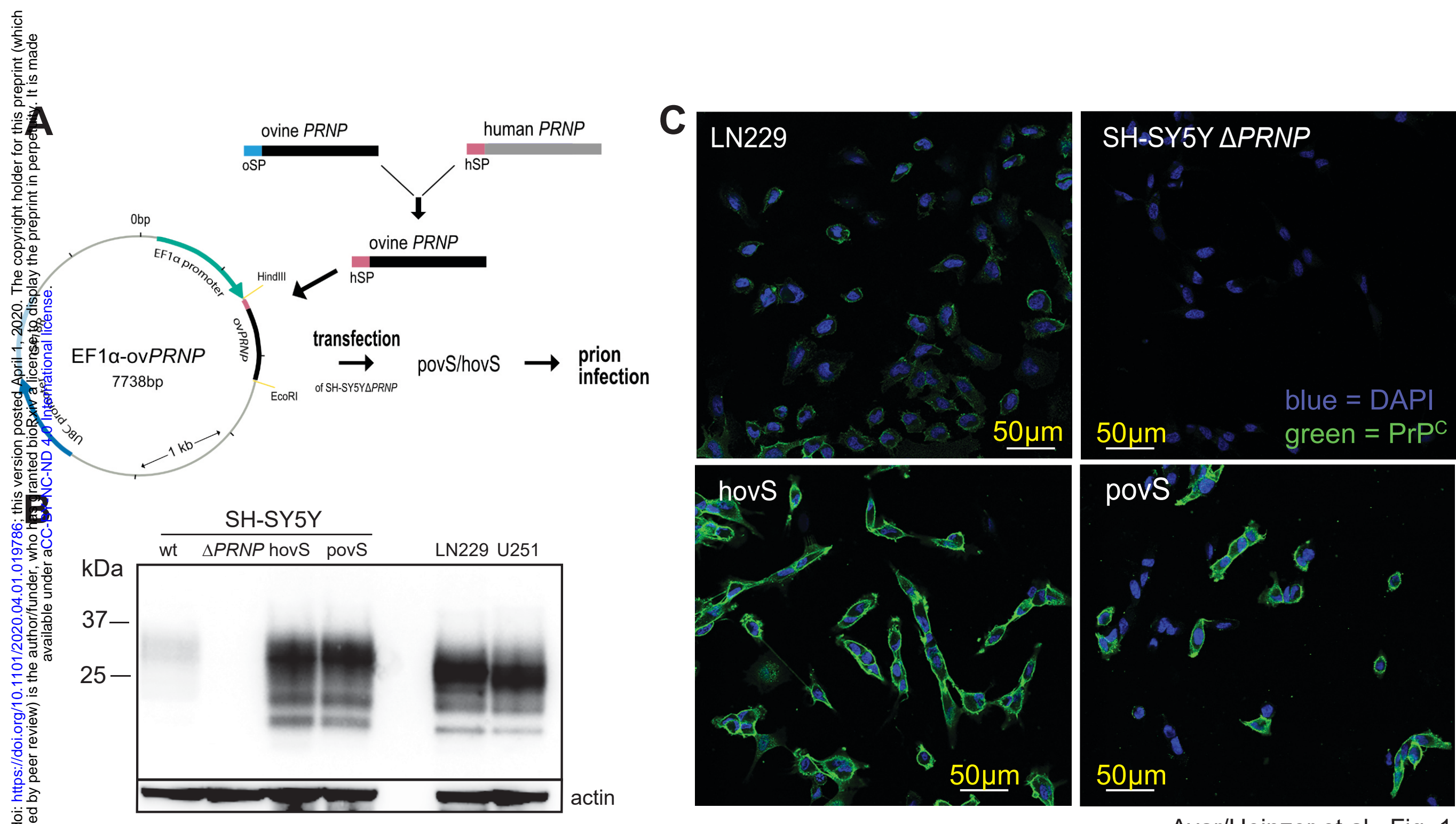

Avar/Heinzer et al., Fig. 1 


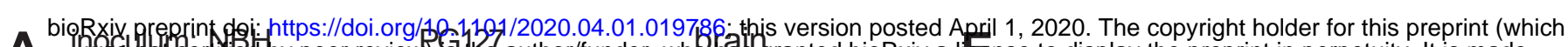

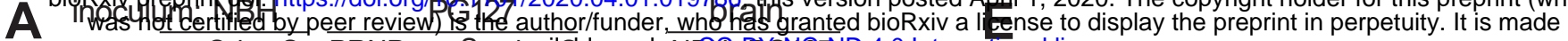

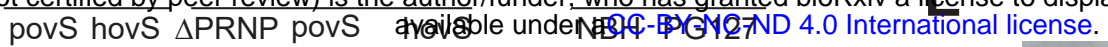
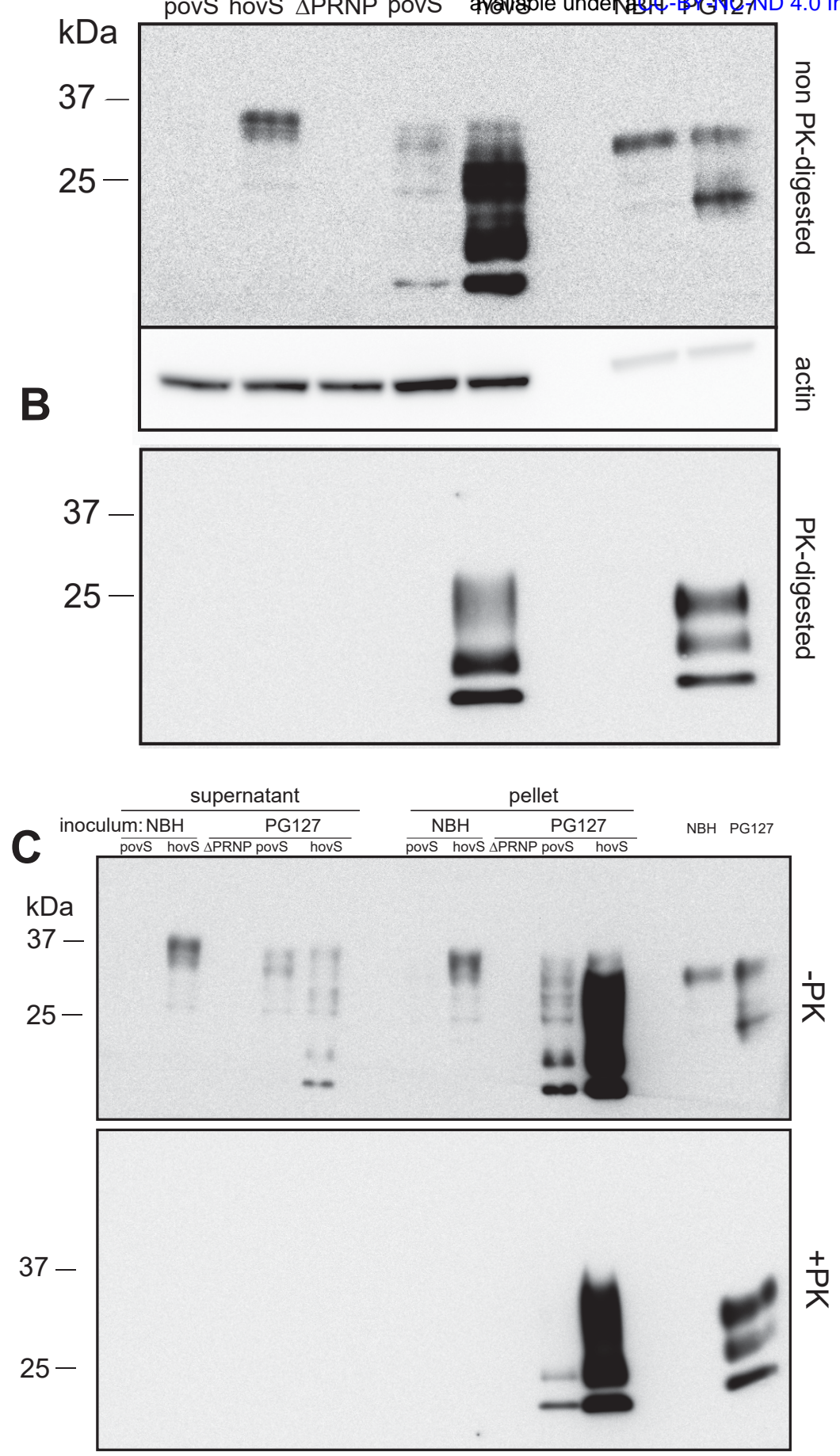

D

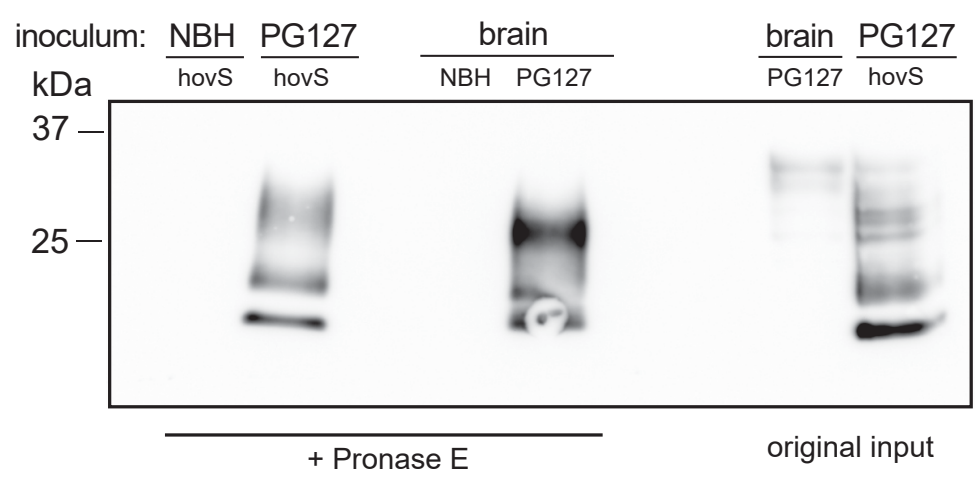

$\stackrel{\stackrel{2}{ٍ}}{\Xi}$

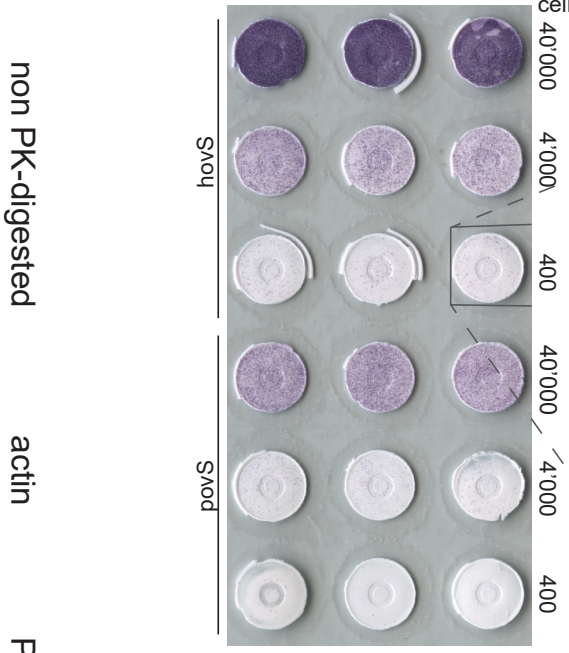
cells:
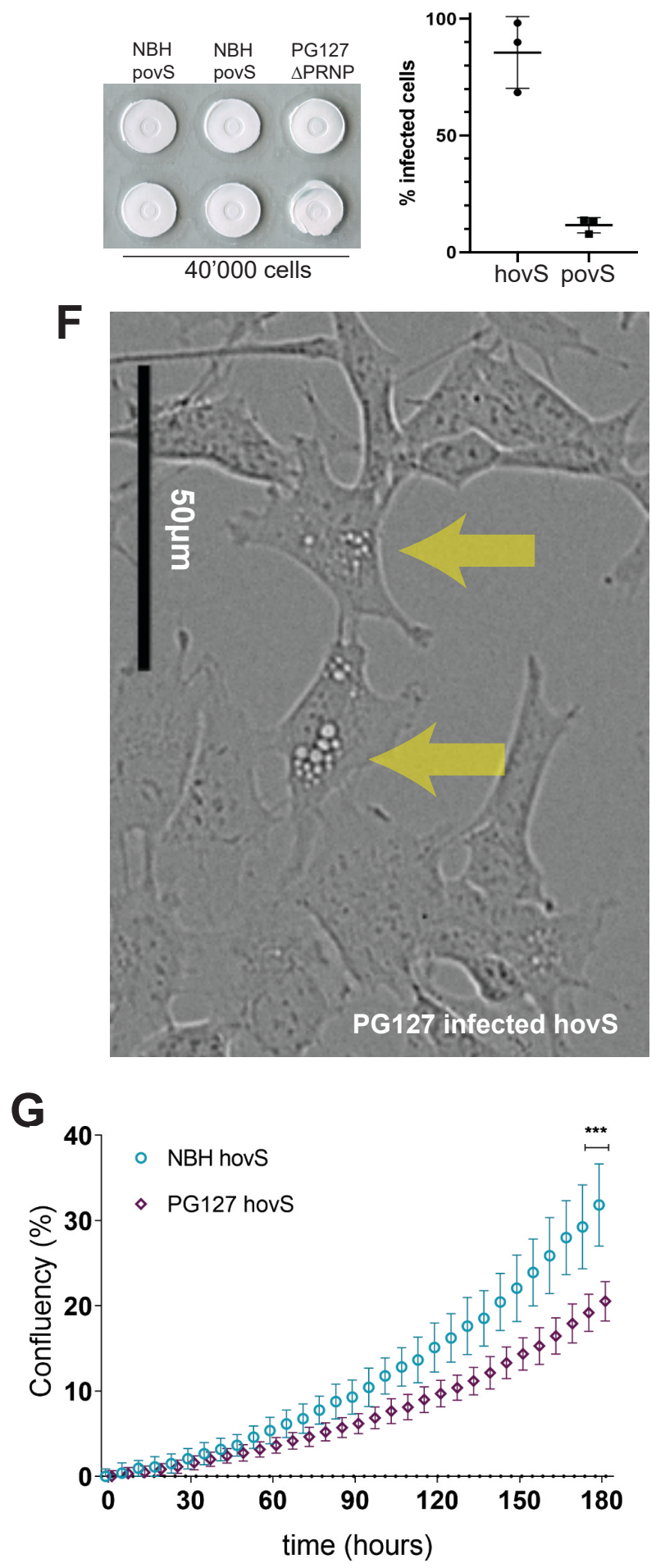

Avar/Heinzer et al., Fig. 2 
bioRxiv preprint doi: https://doi.org/10.1101/2020.04.01.019786; this version-posted April 1, 2020. The copyright holder for this preprint (which

was not cettified by peer review) is the author/funder, who has granted b 0 \%xiv a license to display the preprint in perpetuity. It is made — povs NBH 1:250
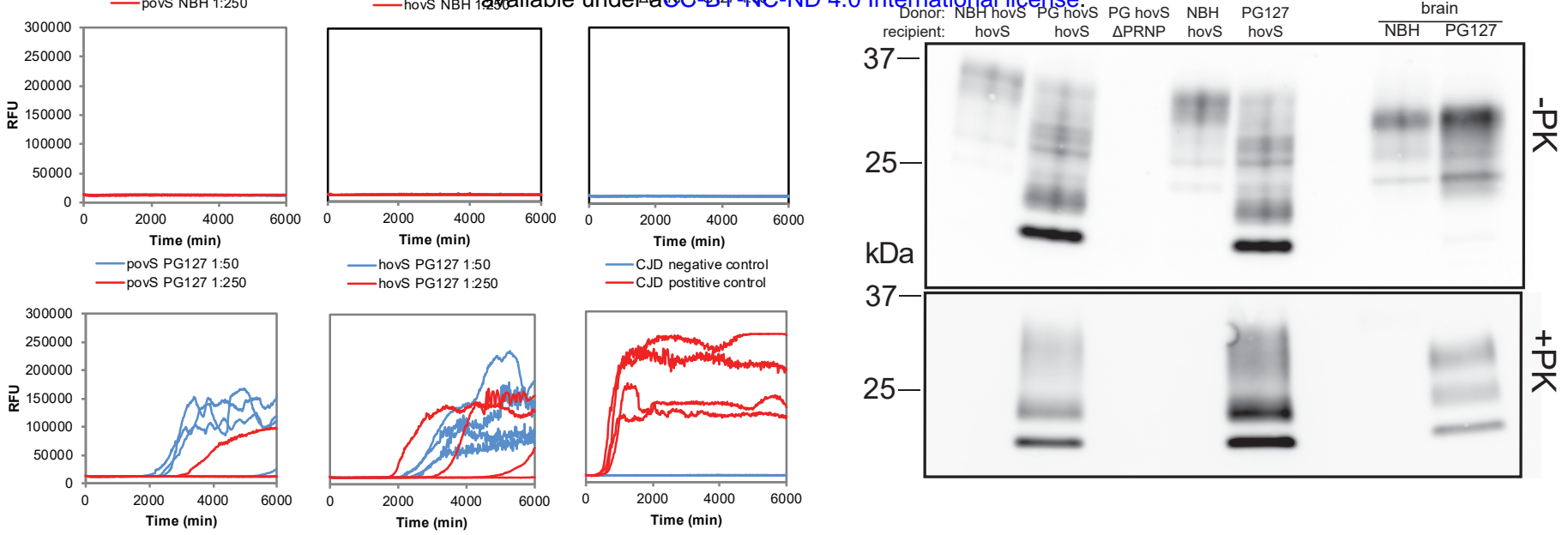

C

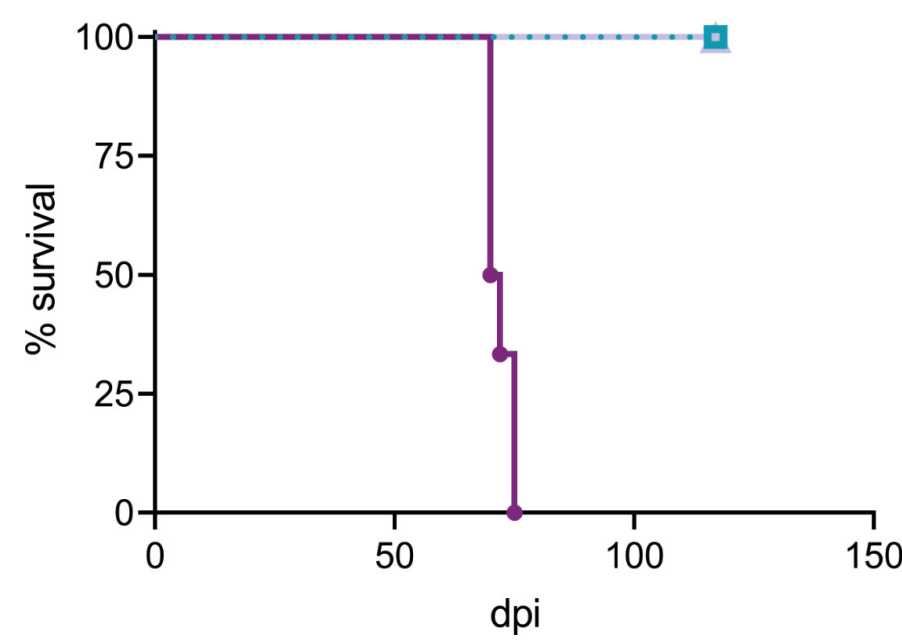

$\sim$ PG127 infected hovS lysate

ㅁ. NBH infected hovS lysate

- PG127 infected $\triangle$ PRNP lysate

D
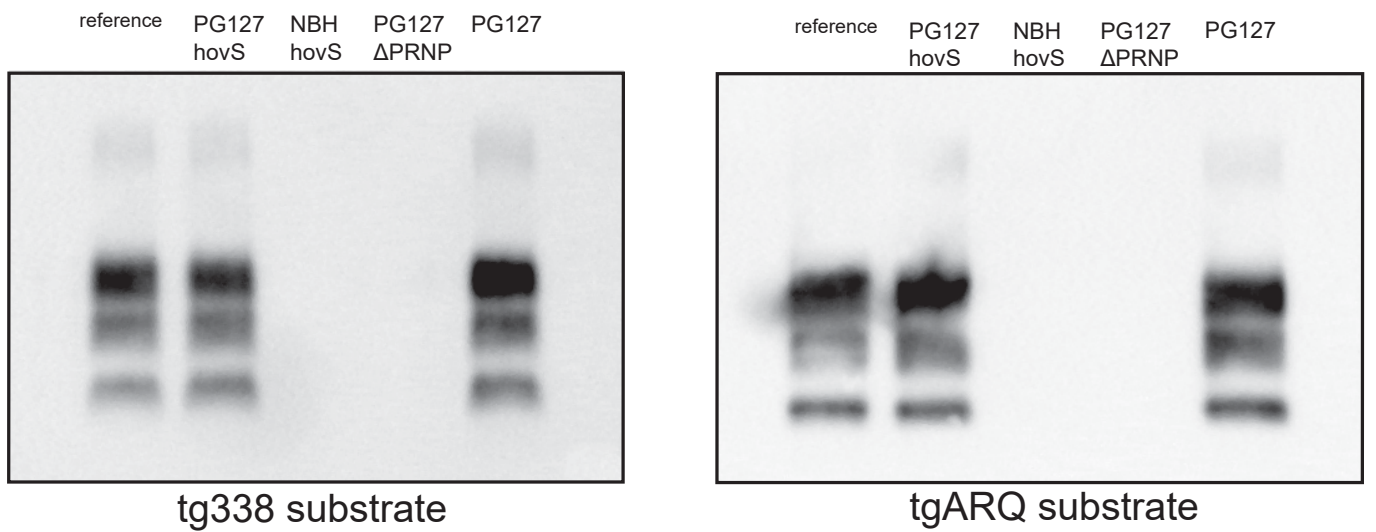

reference PG127 NBH PG127 PG127 SCJD hovS hovS $\triangle$ PRNP

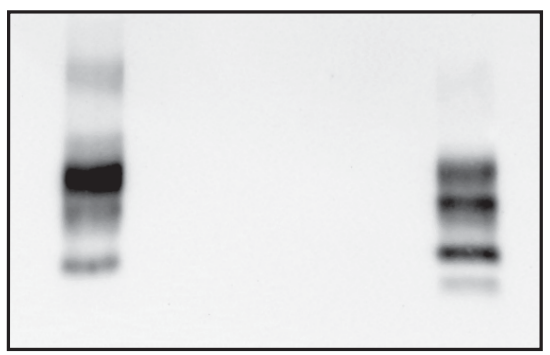

$\operatorname{tg} 650$ substrate

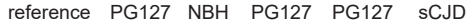
hovS hovS $\triangle$ PRNP

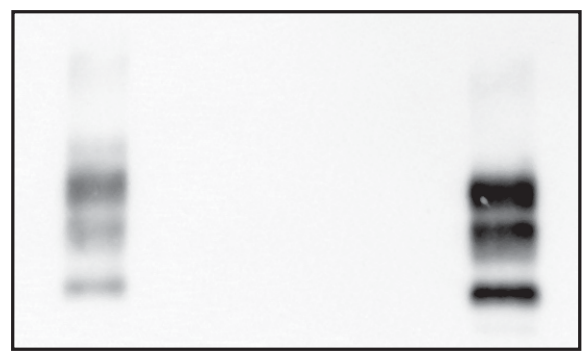

$\operatorname{tg} 361$ substrate reference PG127 NBH PG127 PG127 BSE hovS hovS $\triangle$ PRNP

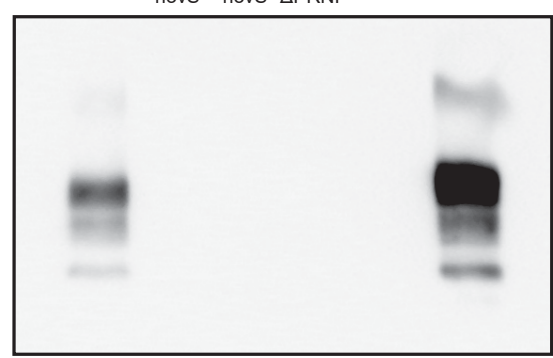

tgBov substrate 
bioRxiv preprint doi: https://doi.org/10.1101/2020.04.01.019786; this versi Mosted April 1, 2020. The copyright holder for this preprint (which was not certified by peer review) is the author/funder, who has granted bigRxiv a license to display the preprint in perpetuity. It is made available under aCC-BY-NC-ND 4.0 International license.
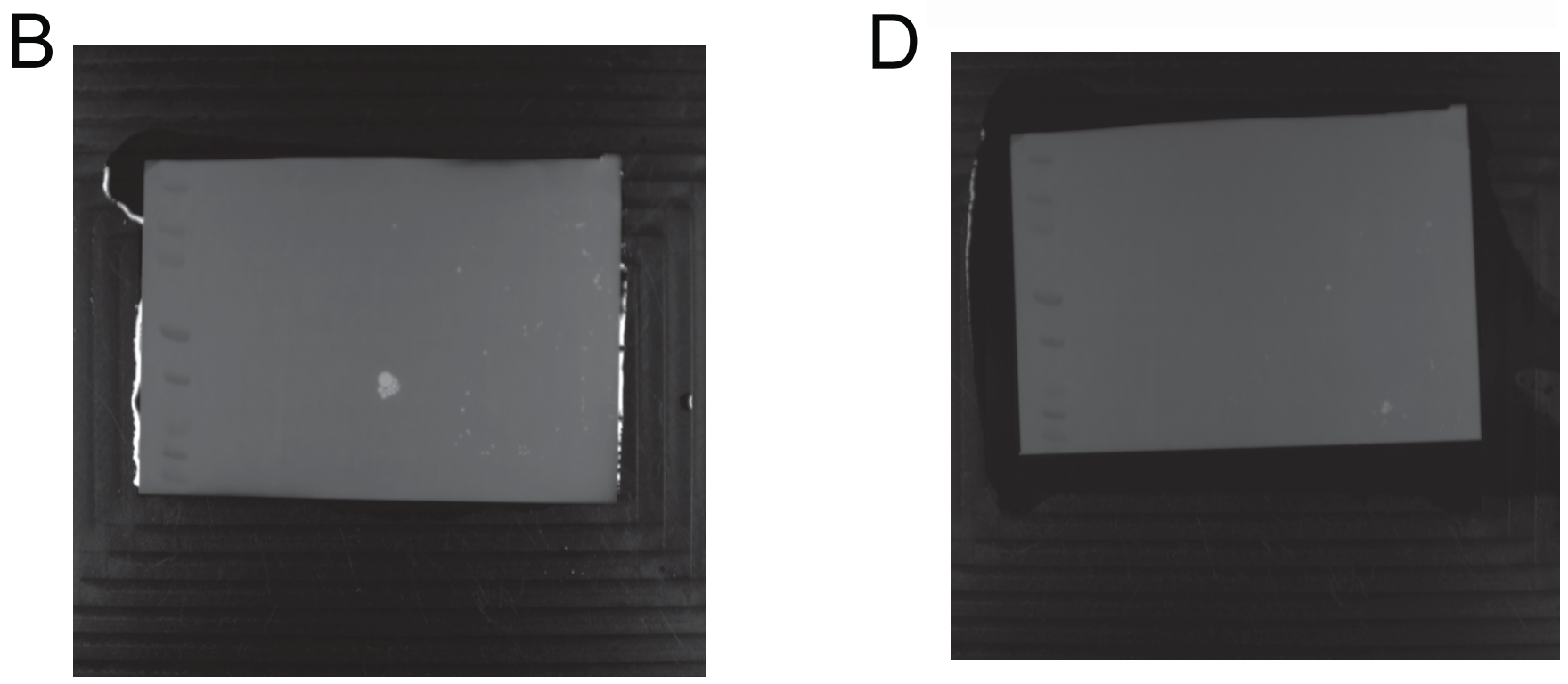

\section{Avar/Heinzer et al., Supplementary Fig. 1}


bioRxiv preprint doi: https://doi.org/10.1101/2020.04.01.019786; this version posted April 1, 2020. The copyright holder for this preprint (which was not certified by peer review) is the author/funder, who has granted bioRxiv a license to display the preprint in perpetuity. It is made

B

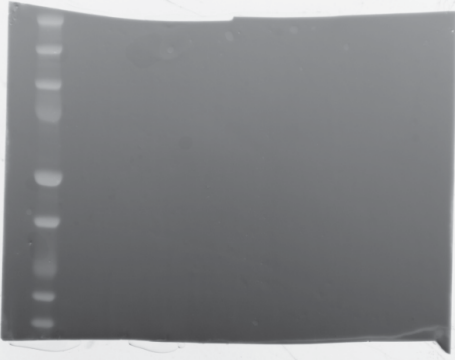

D

G

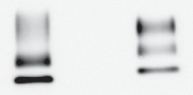

F

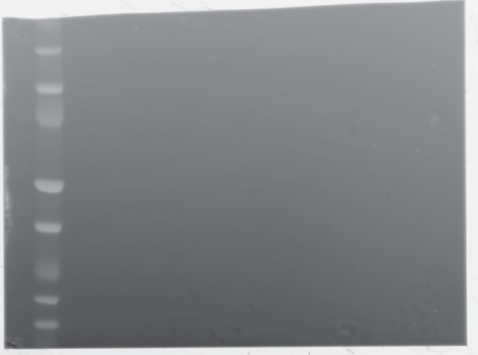

$\mathrm{H}$
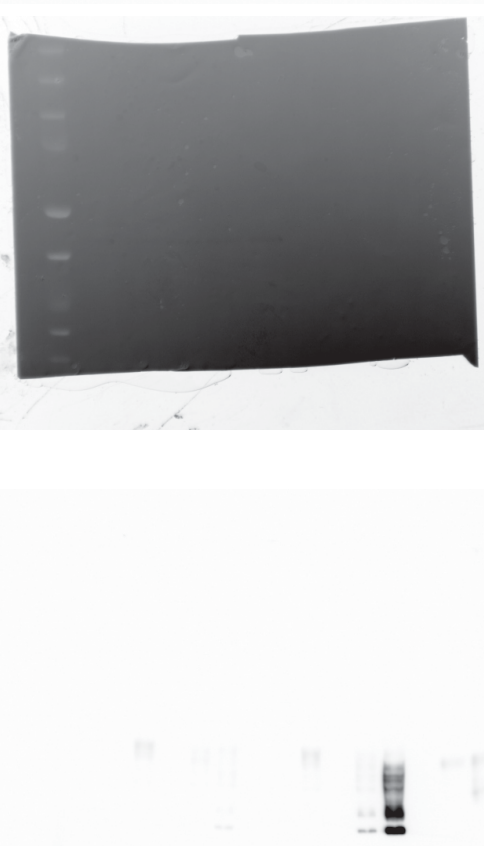

K
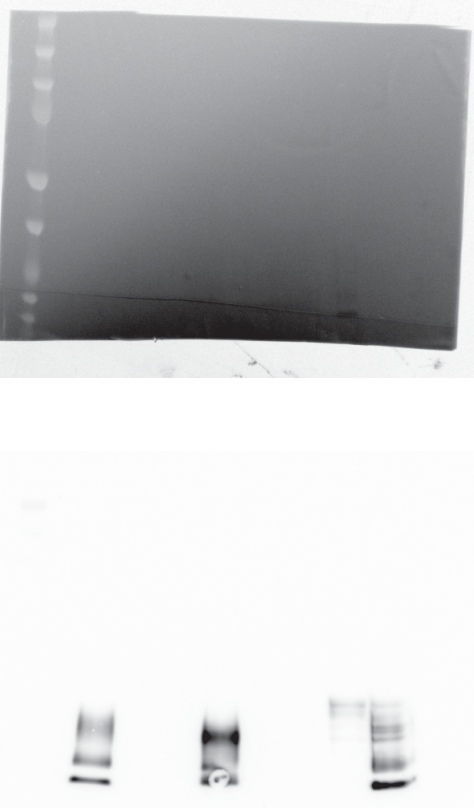

L

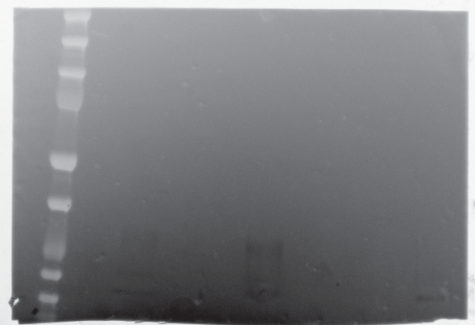


$\Delta$ bioRxiv preprint doi: https://doi.org/10.1101/2020.04.01.019786; thigversion posted April 1, 2020. The copyright holder for this preprint (which was not certified by peer review) is the author/funder, who has ganted bioRxiv a license to display the preprint in perpetuity. It is made available under aCC-B 4 C-ND 4.0 International license.

C

D

$E$

Avar/Heinzer et al., Supplementary Fig. 3 